\title{
Adaptation and Validation of Cognitive Emotion Regulation Questionnaire (CERQ) in Indonesian Version
}

\author{
Endang Prastuti \\ Faculty of Education of Psychology, Malang State University \\ endang.prastuti.fppsi@um.ac.id. \\ Mareyke Maritje Wagey Tairas \\ Faculty of Psychology, Airlangga University \\ marreyke.tairas@psikologi.unair.ac.id. \\ Nurul Hartini \\ Faculty of Psychology, Airlangga University \\ nurul.hartini@psikologi.unair.ac.id.
}

\begin{abstract}
The aim of this research is to adapt and validate the Indonesian version of CERQ for adult samples. CERQ consists of nine emotional regulation strategies, with a total of 36 items. CFA (Confirmatory Factor Analysis) was used to analyse the data. The results of the study showed that based on the measurement model using CFA, CERQ totaling 36 items, through the item selection process, the remaining 17 items have high loading factor. Based on the results of the evaluation of the fit of model indicated by the parameters: chi square = $103.1 \mathrm{I} 5(\mathrm{p}=0.10 \mathrm{I}), \mathrm{GFI}=0.895, \mathrm{AGFI}=0.8 \mathrm{I}, \mathrm{CFI}=0.979, \mathrm{TLI}=0.967$ and $\mathrm{RMSEA}=0.044$ explaining the existence of good goodness of fit. CERQ Indonesian version also has Composite Reliability (CR) in the range of 0.707-0.925 and AVE in the range of 0.786-0.927, also explaining and providing evidence of good convergent validity. The confirmed CERQ measurement model has a fit model according to empirical data. Thus, the Indonesian version of CERQ is accepted as a measure of emotion regulation, especially for young adult respondents (aged 20-40 years).
\end{abstract}

Keywords: adaptation \& validation, CERQ, adult sample

Received 14 November 2019/Accepted 19 May 2020 CJEHCP All rights reserved

\section{Introduction}

Emotion regulation is an individual's effort to influence emotions, how to experience emotions that are felt and express those (Gross, 1998). Based on the work process, emotion regulation can operate automatically (unconsciously) and controlled (Mauss, et al., 2007). Emotional regulation in individuals consist of adaptive and mal-adaptive strategies (Garnefski et al., 200I). Adaptive emotional regulation provides benefits related to affective function, social interaction and wellbeing; whereas less adaptive emotional regulation has the potential to give a negative impact (Gross \& John, 2003). In other words, individuals who have difficulty regulating adaptive emotions can lead 
to psychopathological behavior (Gross, 2015). Less adaptive emotional regulation strategies such as rumination and suppression has a strong influence on psychopathological symptoms such as depression, anxiety, self-blame and catastrophizing (Aldao \& Nolen-Hoeksema, 2010). Adaptive emotional regulation such as positive refocusing and positive reappraisal are negatively related to depression and anxiety, (Garnefski, et al., 200I), low happiness and life satisfaction (Saxena et al., 20II; Yigit, et al., 20I4). Emotional regulation contributes towards subjective well-being and mental health (Prastiti \& Rini, 2016).

Emotional regulation becomes an indicator of happiness, well-being, and life satisfaction. For this reason, developing an emotional measurement tool that plays a role in providing an individual emotional regulation profile will provide an overview of the conditions of happiness, well-being and life satisfaction. Emotion Regulation Questionnaire (ERQ) is designed to assess regulation of emotion using suppression and re-appraisal strategies. Exploratory and confirmatory analysis factors provide evidence that both factors are independent in a sample of young adult women. The ERQ emotion regulation instrument, consisting of two-scale appraisal scale, consisting of 6 items, has an internal consistency of 0.79 and a suppression scale consisting of 4 items. Overall ERQ has an internal consistency of 0.69 (Gross \& John, 2003). ERQ has been widely used to measure emotional regulation.

Further development, a measure of emotion regulation focused on measuring regulation of emotion namely the Cognitive Emotion Regulation Questionnaire (Garnefski, et al., 200I). CERQ consists of 36 items to assess nine cognitive regulation emotion strategies. CERQ consists of two factors. The first factor, called positive-focused cognitive emotion regulation, is theoretically more adaptive, consisting of subscales: (a) positive re-appraisal, (b) putting into perspective, (c) positive refocusing, (d) refocusing in planning, (e) acceptance. The second factor, called negative-focused cognitive emotion regulation, consisting of subscales: (a) self-blame, (b) blaming others, (c) rumination, (d) catastrophizing. Sub-scale reliability after follow-up moved from $0.68-0.83$, and the reliability of the whole scale was 0.92. Cognitive Emotion Regulation Questionnaire (CERQ; Garnefski, et al., 200I; 2002) is an instrument to measure emotional regulation cognitive is considered more comprehensive, compared with ERQ (Gross \& John, 2003), because it has broadly elaborated into nine cognitive strategies for emotional regulation, not only suppression and re-appraisal strategy (Gross \& John, 2003). 
CERQ adaptation has been carried out in several language versions. CERQ standardization has been tested in adolescent and adult groups for the Romanian population with $N=1807$, showing that CERQ has validity and reliability related to personality traits, anxiety symptoms and depression (Perte \& Miclea, 20I I). Adaptation of CERQ for the adult population, using French has been done with sample young adult. The research show that nine-factor models are confirmed by data empirical. The internal consistency of each emotion regulation strategy ranges from $0.68-0.87$. Relevant to the original version of CERQ, self-blame and rumination are emotional regulation strategies that can predict the high and low symptoms of depression (Germany, et al., 2006). CERQ for the adult population has been adapted using the German language involving 414 participants. The results of the research prove that the nine-factor models can be replicated with good reliability. It was concluded that based on literature review, the adult version of CERQ (Garnefski et al., 200I) has not been adapted for the Indonesian population, especially the goddess sample, because this research is important and urgent to do.

The purpose of this study is to adapt CERQ related to cultural and linguistic aspects, so that the Indonesian version of CERQ emotion regulation is produced which has high validity and reliability, to measure the emotional regulation of adult samples (20-40 years). In the Indonesian population, CERQ can act as a tool that can identify the patterns of emotional regulation and predict to happiness, psychological well-being, life satisfaction and mental health.

\section{Method}

Research Phase I: CERQ Language Adaptation

Subject

Subjects involved in the study totaled 118 subjects, with the following details. The translator consists of 2 people with an SI English education qualification, and a translator educating a Masters in Psychology, with English language competence, then the back translation stage involves an expert judgment consisting of 6 experts, namely one professional translator in the field of English, one psychologist educated as a Doctor and one Professor of Psychology and one Professor of English as an expert judgment. CERQ-the Indonesian version before being used was given to 10 adult individuals to find out the subject's understanding of the final CERQ draft-the Indonesian version. 
Field trials to examine the psychometric properties of the Indonesian version of CERQ were given to 102 adults, mothers, high school education, 20-40 years of age.

\section{Instrument}

Emotional regulation measurement tool that will be adapted in this study is the Cognitive Emotion Regulation Question (CERQ; Garnefski, et al., 200I). CERQ consist of 36 items and using a scale of I-5. This means that subjects are asked to provide answers to statements, I (very rare), 2 (rare), 3 (sometimes), 4 (often), 5 (very often). CERQ has an internal consistency of 0.68-0.86. The CERQ was designed to measure nine cognitive-emotional regulation strategies: positive reappraisal, putting into perspective, positive refocusing, refocusing in planning, acceptance, self-blame, blaming others, rumination, catastrophizing (Garnefski,et al., 2002; 2007).

\section{Research Procedure}

Procedure of Adaptation CERQ (Beaton,et.al.,2000).

\section{The Stage of Forward Translation CERQ}

The translation is done with the aim of equivalence of concepts of words and phrases, not only word-for-word translation (literal translation). The initial translation in Indonesian was the subject of discussion, questions and suggestions on the choice of certain words and their expression by a panel of experts (expert panel), which consisted of the original translator and three psychologists. After the expert panel provides the review, the final result is to approve CERQ as the initial draft of the Indonesian version.

\section{The Stage of Back Translation CERQ}

The back translation stage is carried out by experts. The back translation steps are as follows: (I) The Indonesian version of the CERQ emotion regulation measurement tool is re-translated by a professional English translator. (2) The results of the re-translation into English are re-tested for the suitability of their meaning, by comparing the original measuring instrument with a translation repeated by discussing and providing assessment through an assessment questionnaire. (3) Modification of the writing of the Indonesian version of the item is made, so it is more in line with the Indonesian language style and Indonesian cultural context. (4) Results at this stage will produce an Indonesian version of the final CERQ draft which is ready to be trialed. 
The Pilot Study Stage

Pilot Study stage (pre-try out) aims to verify the Indonesian version of the CERQ items related to test instructions, understanding of items and ease the administering tests. Based on input from the subject of the trial, then it was reformulated the work instructions, changing the use of words that are better and more appropriate to Indonesian speakers. After the repairs are made, the Indonesian version of CERQ in the final form is ready for use.

A draft of the CERQ measuring instrument was given to 10 adult individuals to determine respondents' understanding of the CERQ draft. The results of the pilot study showed that respondents had no difficulty in understanding the Indonesian version of CERQ items. Next, the final draft is arranged, so that the Indonesian version of CERQ is ready for field trials with a wider sample, to test the validity and reliability of the measuring instrument.

Research Phase 2: Measurement Validation of CERQ

Research Purposes

The purpose of the second stage of the research is to confirm the CERQ measurement model and validate the Indonesian version of CERQ. The step aims to test the suitability of empirical data and the quality of psychometric measuring devices.

\section{Subject}

This study involved 102 participants, with the characteristics: being a mother and having children, aged between 20-40 years, high school education level and tertiary education, work status: working/not working, and stating willingness to be the subject of research, evidenced by filling out statements willing to be the subject of research based on the principle of informed consent and provide protection related to the confidentiality of subject data (Nevid, et al., 2005).

\section{Data Analysis}

The Stage: Selecting CERQ items

This selection stage is divided into three parts. First part is the initial item selection with consideration of the loading factor value. Second, the selection of advanced items with consideration of the value of standardized residual covariance, this stage is carried out when the 
goodness of fit is not good. Third, the final item selection with consideration to get a CFA model that has good goodness of fit.

\section{The Stage to determining the Validity and Reliability}

The results of the selected items will be calculated convergent reliability based on the Alpha Cronbach coefficient, the Composite Reliability (CR) coefficient and the Average Variance Extracted (AVE) value. The accuracy of each selected item will be confirmed through the results of the calculation of discriminant validity and cross-loading values.

\section{Result}

Research Phase I:

The Stage of Forward Translation

The forward translation steps are as follows: (I) Two translators translate CERQ's emotional regulation measurement tools into Indonesian; (2) The results of translation are seen through equality through discussions and the results of the assessment questionnaire conducted by 3 experts with English competence and understanding the construct that is translated. The expert panel consists of one Professor and 2 Doctor of Psychology. The results of the expert analysis in stages of forwarding translation are shown in the following description.

CERQ consists of 9 aspects. Each aspect consists of 4 items. So, the total items are 36 items. The result of forward translation concludes that overall the aspects of emotion regulation have high translation equivalency from translator $A$ and $B$. High equivalency mainly showed in item translation of emotion regulation in aspect of (I) self-blame, (2) refocus on planning (3) putting into perspective (4) refocus on planning (5) catastrophic (6) blaming other.

There is little difference in translation, related to choice of words used in item translation of emotion regulation. (I) emotional regulation aspects of acceptance items consist of 4 items, judged by experts to have equivalent translations, except for item number 3. Translator B translates I think into I feel, whereas translator A means I think. According to the expert panel "I think and I feel" does not have the same meaning (2) emotion regulation aspect of rumination: results of expert assessments conclude that the emotional regulation items of the rumination aspect consisted of 4 
items, judged to have equivalent translations, except for item number 4 which reads: "I dwell upon" translated by translator A: I reflect, while translator B: I think. In accordance with the concept of rumination, the correct translation is "thinking". (3) emotion regulation aspect of positive refocusing: the results of expert judgment conclude that the emotional regulation items of positive refocusing aspects consist of 4 items, judged by experts to have equivalent translations. There is a slight difference in the translation of items: "I think of nicer things is better" translated "I think of pleasant experiences".

\section{The Stage of Back Translation}

The results of forwarding translation (draft Indonesian version), then back translation (English version) is carried out by professional translators. Re-translation into English, the suitability of its meaning is tested again, by comparing the original measuring instrument with a re-translation by a linguist. The result of the expert panel's assessment stated that all CERQ items numbered 36, consisting of nine aspects with each aspect consisting of 4 items, concluded to have the same meaning. There are slight differences related to grammar and word choice, but overall there is the same meaning of back translation, when compared to the original item in nine aspects of CERQ.

Emotional regulation aspects of self-blame, according to the study of language experts that: the translation of the word "I think" is not the same as the word "I feel" Furthermore, the emotion regulation aspects of acceptance experts provide a revised note related to the translation of items that read: "I think that I must learn to live with that ", back translation reads:" I think that I should live along with that problem ", is not appropriate because there is the keyword "I must learn "(I must learn) not appear in the statement so that it is considered less worth the meaning of the original item. The emotional regulation of the rumination aspect of language provides a revised note related to back translation items that read: "I am preoccupied with thoughts and feelings about what I have experienced," where the word "preoccupied" is the translation of "I am preoccupied", the back translation becomes "I have been busy with thoughts and feelings on anything I have experienced". Forward translation of the word I am preoccupied, in the psychological context it is more appropriate to translate it with "I'm fixated with thought ..." or "I'm preoccupied with ...", not I'm busy ..." 
Emotional regulation positive refocusing aspects, experts provide revised notes related to the translation of the word "I think of fun things that have nothing to do with it". The word "fun" is more accurately translated as "pleasant things", not "fun things". Actually both translations have similar meanings, but the choice of pleasant words which means fun is more appropriate than the word fun. Emotional regulation of aspects of refocus on planning on the item "I think of how to cope with the situation in the best way" translates into "I think about how to overcome a situation in the best way", already considered to have the same meaning as the original item that reads "I think about how I can best cope with the situation ", although in the context of psychology "to cope" is considered more appropriate than "overcome".

Emotional regulations on positive reappraisal aspects: that all items have the same meaning, grammar and choice of words, so there is a match between back translation and the original item. Furthermore, emotional regulation puts aspects into perspective, according to the assessment of language experts: all items have the same meaning, grammar and choice of words, so there is a match between back translation and the original item. Emotional regulation of catastrophizing aspects reads: "I keep thinking about how terrible the situation is", after a back translation was made: "I keep going on thinking, how terrifying that situation was", judged by experts there was a slight difference in grammar, but did not change the meaning when the sentence to: "I continually think how horrible the situation has been". Furthermore, emotion regulation aspects blame others show that all items have the same meaning, grammar and word choice, so there is a match between back translation and the original item.

\section{Research Phase 2}

The purpose of research phase 2 is to test the Indonesian version of the CERQ measurement model and validate the CERQ. The stages of analysis are (a) selecting selected items, (b) proof of validity and reliability.

\section{Item Selection Stage}

The total number of items in the emotional regulation construct is 36 . Based on the initial CFA model, namely item selection, and refers to the loading factor value. The results show several aspects of having items with a loading factor of less than 0.50 , namely: self-blame ( $I$ item), acceptance ( $\mathrm{I}$ item), rumination ( 2 items), putting into perspective (2 items) and blaming others (I 
item). In the first part of this initial stage, out of 36 items, 7 items were removed, remaining 29 items. The results of the evaluation of the model fit are shown with the following parameters: chi square $=1 \mid 42,533(p=0.00), \mathrm{GFI}=0.618, \mathrm{AGFI}=0.544, \mathrm{CFI}=0.776, \mathrm{TLI}=0.747$ and $\mathrm{RMSEA}=$ 0.102. This data explains that the measurement model has not shown good goodness of fit (Crocker \& Algina, 2008).

The next selection process loading factor is no longer a consideration in selecting items because it has a value of more than 0.50 but it shifts to decisions based on the value of standardized residual covariance. The final CFA model, illustrating the loading factor for 17 selected items, has a total value of more than 0.50 . The results of the evaluation of the model fit are indicated by the parameters: chi square $=103.115(p=0.10 I), G F I=0.895, A G F=0.8 I 4, C F I=0.979, \mathrm{TLI}=0.967$ and RMSEA $=0.044$ explaining the well good of fit. The chosen selection item results are shown in table I below.

Table I

Results of selection item of emotion regulation

\begin{tabular}{|c|c|c|}
\hline $\begin{array}{l}\text { Emotion Regulation } \\
\text { Aspects }\end{array}$ & CERQ (Indonesian Version) & Loading Factor \\
\hline \multirow[t]{2}{*}{ Self-blame } & $\begin{array}{l}\text { I feel that I am the one to blame for it. } \\
\text { (Saya merasa bahwa sayalah orang yang patut disalahkan untuk hal } \\
\text { itu) }\end{array}$ & 0.79 \\
\hline & $\begin{array}{l}\text { I fell that I am the one who is responsible for what has happened } \\
\text { (Saya merasa bahwa sayalah yang bertanggungjawab terhadap hal } \\
\text { yang telah terjadi) }\end{array}$ & 0.81 \\
\hline \multirow[t]{2}{*}{ Acceptance } & $\begin{array}{l}\text { I think that I have to accept that this has happened } \\
\text { (Saya berpikir bahwa saya harus menerima apa yang sudah terjadi) }\end{array}$ & 0.90 \\
\hline & $\begin{array}{l}\text { I think that I have to accept the situation. } \\
\text { (Saya berpikir bahwa saya harus menerima situasi ini) }\end{array}$ & 0.96 \\
\hline \multirow[t]{2}{*}{ Rumination } & $\begin{array}{l}\text { I am preoccupied with what I think and fell about what I } \\
\text { experienced. } \\
\text { (Saya disibukkan dengan pikiran dan perasaan mengenai apa yang } \\
\text { telah saya alami) }\end{array}$ & 0.76 \\
\hline & $\begin{array}{l}\text { I dwell upon the feeling to situation has evoked in me. } \\
\text { (Saya merenungkan perasaan (saya) mengenai situasi yang terjadi pada } \\
\text { diri saya) }\end{array}$ & 0.84 \\
\hline
\end{tabular}


Refocus on planning

Positive reappraisal

Putting into perspective

Catasthrophizing

Blaming others
I think about how to change the situation

(Saya berpikir bagaimana untuk mengubah situasi)

I think about a plan of what I can do best

(Saya berpikir tentang rencana terbaik yang bisa saya lakukan)

I think I can learn something from situation

(Saya berpikir bahwa saya dapat belajar sesuatu dari situasi ini)

I think that I has not been too bad compared to other things

(Saya berpikir bahwa saya tidak terlalu buruk, dibandingkan orang lain)

I keep thinking about how terrible it is what I have been experienced.

(Saya terus memikirkan betapa mengerikan apa yang saya alami)

I feel that others are blame for it.

(Saya merasa bahwa orang lain yang perlu disalahkan untuk itu)

I fell that others are responsible for what has happened.

(Saya merasa bahwa orang lain yang bertanggungjawab atas apa yang sudah terjadi)

I think about the mistakes others have made in the matter. ini)

\section{The Stage Determining Validity and Reliability}

This stage of the analysis is carried out using CFA methods to examine the construct validity and the reliability of the measuring instrument as a whole as well as per subscale. The results of the construct validity calculation are based on several convergent validity calculations such as loading factor, composite reliability (CR) and Average Variance Extracted (AVE). 
Table 2

Validity \& Reliability of CERQ

\begin{tabular}{|c|c|c|c|c|c|}
\hline Aspects & Selected Items & Loading Factor & $\begin{array}{l}\text { Alpha } \\
\text { Cronbach }\end{array}$ & $\begin{array}{l}\text { Composite } \\
\text { Reliability }\end{array}$ & $\begin{array}{l}\text { Average Variance } \\
\text { Extracted (AVE) }\end{array}$ \\
\hline \multirow[t]{2}{*}{ Self Blame } & REII & 0.836 & 0.817 & 0.819 & 0.833 \\
\hline & REI2 & 0.830 & & & \\
\hline \multirow[t]{2}{*}{ Acceptance } & RE2I & 0.954 & 0.924 & 0.925 & 0.927 \\
\hline & RE22 & 0.900 & & & \\
\hline \multirow[t]{2}{*}{ Rumination } & RE32 & 0.829 & 0.761 & 0.764 & 0.786 \\
\hline & RE34 & 0.742 & & & \\
\hline \multirow[t]{3}{*}{ Positive refocusing } & RE4I & 0.684 & 0.702 & 0.707 & 0.668 \\
\hline & RE42 & 0.663 & & & \\
\hline & RE43 & 0.657 & & & \\
\hline \multirow[t]{2}{*}{ Refocus on planning } & RE53 & 0.939 & 0.919 & 0.921 & 0.924 \\
\hline & RE54 & 0.909 & & & \\
\hline Positive reappraisal & RE63 & 1.000 & 1.000 & 1.000 & 1.000 \\
\hline Putting into perspective & RE73 & 1.000 & 1.000 & 1.000 & 1.000 \\
\hline Catastrophizing & RE82 & 1.000 & 1.000 & 1.000 & 1.000 \\
\hline \multirow[t]{3}{*}{ Blaming others } & RE9I & 0.863 & 0.897 & 0.900 & 0.865 \\
\hline & RE92 & 0.919 & & & \\
\hline & RE93 & 0.813 & & & \\
\hline Overall & & & $0.79 \mid$ & 0.884 & 0.855 \\
\hline
\end{tabular}

Table 2 shows that the loading factor having a value in the range of 0.702-0.924 fulfills a good condition because it is worth more than 0.50 . Composite Reliability (CR) in the range of 0.707 0.925 with a value of more than 0.70 and AVE in the range of $0.786-0.927$ with a value of more than 0.50 provide evidence of good convergent validity. The calculation results for all items selected in this construct also have good convergent validity. Meanwhile, the discriminant validity of an aspect is done by comparing the root value of AVE with all the correlation coefficients between these aspects and other aspects. If the root value of AVE is greater than the correlation coefficient, then this aspect has good discriminant validity. The results of the analysis in Table 3 explain that all aspects of emotional regulation have good discriminant validity. 
Table 3

Discriminant Validity of Emotional Regulations

\begin{tabular}{llllll}
\hline & & \multicolumn{3}{c}{ Correlation Coefficients } \\
\cline { 3 - 6 } Aspect & AVE Root & Self Blame & Acceptance & Rumination & $\begin{array}{l}\text { Positive } \\
\text { Refocusing }\end{array}$ \\
\hline \hline Self Blame & 0.913 & 1.000 & - & - & - \\
Acceptance & 0.963 & 0.535 & 1.000 & - & - \\
Rumination & 0.886 & 0.252 & 0.341 & 1.000 & - \\
Positive Refocusing & 0.817 & 0.147 & 0.321 & 0.112 & 1.000 \\
Refocus on Planning & 0.961 & 0.138 & 0.224 & 0.358 & 0.374 \\
Positive Reappraisal & 1.000 & 0.383 & 0.389 & 0.115 & 0.370 \\
Putting into Persp & 1.000 & 0.318 & 0.211 & -0.015 & 0.442 \\
Catastrophizing & 1.000 & 0.298 & 0.032 & 0.646 & 0.033 \\
Blaming others & 0.930 & 0.395 & 0.039 & 0.420 & 0.003 \\
\hline
\end{tabular}

Table 3 (Continued)

\begin{tabular}{llllll}
\hline Aspect & $\begin{array}{l}\text { Refocus on } \\
\text { Planning }\end{array}$ & $\begin{array}{l}\text { Positive } \\
\text { Reappraisal }\end{array}$ & $\begin{array}{l}\text { Putting into } \\
\text { Perspective }\end{array}$ & Catastropizing & $\begin{array}{l}\text { Blaming } \\
\text { Others }\end{array}$ \\
\hline Refocus on Planning & 1.000 & - & - & - & - \\
Positive Reappraisal & 0.363 & 1.000 & - & - & - \\
Putting into Persp & 0.135 & 0.445 & 1.000 & - & - \\
Catastrophizing & -0.003 & -0.089 & -0.046 & 1.000 & - \\
Blaming others & -0.238 & -0.034 & 0.113 & 0.746 & 1.000 \\
\hline
\end{tabular}

\section{Discussion}

The results of the expert panel's assessment at the back translation stage, generally concluded that all emotional regulation items contained the suitability and similarity of meaning, grammar and word selection in all aspects of emotional regulation, by comparing "original" items with forward translation. Some items were found to have slight grammatical differences and choice of words, but did not change the overall meaning. So, it could be concluded that there was a match between back translation and the original CERQ items. Some things that can be discussed at the stage of language adaptation are primarily the regulation of emotions in the aspect of self-blame: the translation of the word "I think" is not the same as the word "I feel", because "think" refers to the cognitive domain, while "fell", is an affective construct. Emotional regulation aspects of rumination that read: "I am preoccupied with thoughts and feelings about what I have experienced", is a translation of "I am preoccupied", back translation to "I have been busy with thoughts and feelings on anything I have experienced". This item becomes less simple and too long, while it is more appropriate in the 
psychological context to translate it with "I'm fixated with thoughts ...".Emotional regulation of positive refocusing aspects, item "I think of fun things that have nothing to do with it". The word "fun" is a more appropriate choice of words translated with "pleasant things", not "fun things".

Emotional regulation aspects of refocus on planning on the item "I think of how to cope with the situation in the best way" was translated into "I think about how to overcome a situation in the best way". Dictation or word choice should be related to construct definition, meaning that between "to overcome and to cope" the meaning is the same. Meanwhile, emotional regulation of positive reappraisal aspects: shows that all items have the same meaning, grammar and choice of words, so there is a match between back translations with original items. Emotional regulation puts aspects into perspective, that all items have the same meaning, grammar and choice of words, so there is a match between back translations with "original" items. Translation of emotion regulation catastrophizing aspects reads: "I keep thinking about how terrible the situation is", after a back translation was made to: "I keep going on thinking, how terrifying that situation was", judged by experts there was a slight difference in grammar, but did not change the meaning when the sentence becomes: "I continually think how horrible the situation has been." Back translation emotional regulation aspects: (a) blame others (b) catastrophizing (c) putting into perspective (d) positive reappraisal and (e) accepting that all items have in common meaning, grammar and word selection, so there is a match between back translation and the original CERQ items.

After conducting tests on 102 maternal subjects aged 20-40 years, CERQ consisting of nine aspects, each aspect consisting of 4 items, after selecting items using CFA analysis (Confirmatory Factor analysis), obtained 17 items that have high of loading factors. Overall the CERQ measurement model is compatible or confirmed with empirical data. The results of the selection analysis of this item cannot be compared with the results of other studies especially for the Indonesian population, because so far the Indonesian version of CERQ has not been adapted. However, the results of the study showed that all aspects of CERQ, represented by the quality of items with high loading factor. Thus, the Indonesian version of CERQ can be used as a measurement of emotional regulation in adult samples aged $20-40$ years.

Based on the confirmatory test using CFA analysis proved the CERQ measurement model has conformity with empirical data, indicated by the results of evaluating the suitability of the model 
with chi square $=103.115(P=0.10 \mathrm{I}), \mathrm{GFI}=0.895, \mathrm{AGFI}=0.8 \mathrm{I} 4, \mathrm{CFI}=0.979, \mathrm{TLI}=0.967$ and RMSEA $=0.044$ explains the existence of good goodness of fit. (Crocker \& Algina, 2008). The Indonesian version of CERQ, consisting of 9 aspects, has Composite Reliability (CR) in the range of 0.707-0.925. Overall CERQ has a Composite Reliability (CR) of 0.884 , which is relatively high. The Indonesian version of CERQ validation, proved to be as good quality as the original CERQ, where the reliability of the subscale after follow-up moved from $0.68-0.83$, and the reliability of the entire scale of 0.92 (Garnefski et al., 200I). Likewise, when compared to The French version of the CERQ (German, et al., 2006) was adapted to a sample of 224 young adults, with internal consistency ranging from 0.68 to 0.87 . The results of this study are supporting previous researches, show that 9 factor structures can be confirmed for the German version of CERQ, with good reliability. However, this research validation of CERQ has not been correlated with other variables, such as anxiety and depression, as has been done with the original CERQ (Garnefski, et al., 200I; Loch, Hiller \& Witthoft, 20II).

Indonesian version of CERQ validation has been carried out on adult samples aged 20-40 years, totaling 102 people. The Indonesian version of CERQ has psychometric qualities which are indicated by having high construct validity with high Composite Reliability (CR) as well, so that the CERQ resulting from the adaptation of Indonesian language and culture, can be used to measure emotional regulation in adult samples (aged 20-40 years). The suggestion for the future study is the examination of validity of CERQ should be strengthened by evidence of external source validity, by comparing the Indonesian version of the CERQ with another emotional regulation scale. Predictive validity can also be done by correlating with other variables such as anxiety, depression or subjective well-being. In addition, it is also recommended for further research to perfect CERQ adaptation and validation by involving a wider sample, in adult samples, not only limited to ages 20 40 years, but also involving socio-demographic variations the wider.

\section{Conclusion}

The results of the CERQ adaptation through the forward and back translation stages were strengthened by expert judgment, resulting in an Indonesian-language version of CERQ that has an equivalent in meaning to the original CERQ items. Furthermore, the CERQ adapted from the Indonesian language consists of 9 aspects after the CFA analysis, remaining 17 items with a high 
loading factor. The emotional regulation construct measurement model has been confirmed to have a factor structure in accordance with the original CERQ factor structure, after reducing items that have a loading factor below 0.50. The confirmed CERQ measurement model has a fit model according to empirical data. In addition, the Indonesian version of CERQ can be used to assess emotion regulation to Indonesian sample, because the Indonesian Version of CERQ have a high construct validity, discriminant validity and Composite Reliability (CR). This means that the Indonesian version of CERQ is proven to have psychometric properties as a good measurement tool for measuring emotional regulation, especially young adult respondents (aged 20-40 years) of the Indonesian population.

\section{References}

Aldao, A., \& Nolen-Hoeksema, S. (2010). Specificity of cognitive emotion regulation strategies: A trans diagnostic examination behavior research and therapy, 48, 974-983.

Beaton, D.E., Bombardier, C., Guilemin, F., \& Ferraz, H.B. (2000). Guidelines for the Process of Cross-Cultural Adaptation of Self-Report Measure. SPINE, 25(24), 3186-319I.

Crocker, L., \& Algina, J. (2008). Introduction to classical and modern test theory. New York: Nelson Education, Ltd.

Garnefski, N., \& Kraaij, V. (2007). The cognitive emotion regulation questionnaire: Psychometric feature and prospective relations with depression and anxiety in adults. European Journal of Psychological Assessment, 23(3), I4I-I49.

Garnefski,N., Kraaij,V.,\& Spinhoven,P.(200I). Negative life event, cognitive emotion regulation and emotional problem. Personality and Individual Differences, 30, I 3 I I-I 327.

Garnefski, N., Kraaij, V.,\& Spinhoven, P. (2002). Manual for use of the cognitive emotion regulation questionare. Leiden University.

Gross, J.J. (1998). The emerging field of emotion regulation: An integrative review. Review of General Psychology, 2, 27I-299.

Gross, J. J. (2015).Emotion regulation: Current status and future prospect. Psychological Inquiry, 26, $\mathrm{I}-26$.

Gross, J. J., \& John, O.P. (2003). Individual differences in two emotion regulation processes. Implication for affect, relationship, and well-being. Journal of Personality and Social Psychology, 85,348-362.

Gross, J. J., \& John, O.P. (2003). Individual differences in two emotion regulation processes: Implication for affect, relationship, and well-being. Journal of Personality and Social Psychology, 85, 348-362. 
Jermann, F., Linden, M.V., d'Acremont, M., \& Zermatten, A. (2006). Cognitive emotion regulation questionare (CERQ) confirmatory factor analysis and psychometric properties of the French translation.

Loch, N., Hiller, W., \& Witthoft, M. (20II). Der cognitive emotion regulation questionnaire (CERQ) erste test stistis cheuber prufungeiner deutschen adaption.

Mauss, I.B., Bunge,S.A., \& Gross, J.J. (2007). Automatic emotion regulation. Social and Personality Psychology Compass, 146-167.

Nevid, J.S., Rathus, S.A.,\& Greene, B. (2005). Psikologi Abnormal. (Penerjemah Tim Fakultas PsikologiUI), Jakarta: Penerbit Erlangga.

Perte, A.,\& Miclea, M. (20II). The standardization of the cognitive emotional regulation questionare (CERQ) on Romanian population. Behavior an Interdisciplinary Journal, 15, I I I-I30.

Prastiti, W.D., \& Rini,O.K. (2016). The relation of emotion regulation and subjective well-being in adolescent student. Proceeding of International Conference on Health and Well-Being, I I I- I I8.

Saxena, P., \& Dubey, A., \& Pandey, R. (20II). Role of emotion regulation difficulties in predicting mental health and well-being. Proj. Psy. \& Ment.Health, I8, I47-I55.

Yigit, A., Ozpolat,A.R., \& Kandemir, M.(20I4). Emotion regulation strategies as a predictor of life satisfaction in university students, Psychology, 5, 523-532. 